\title{
Corporal Punishment as a Parental Practice and Anxiety in Pre-adolescent Children
}

\author{
Yosi Yaffe (Corresponding author) \\ Ohalo Academic College, Katzrin, Israel \\ Tel: 972-52-518-4440. E-mail: vabsolut@windowslive.com \\ David Burg \\ Ohalo Academic College, Katzrin, Israel \\ Biomathematics Workgroup, Department of Mathematics, Braude College, Carmiel, Israel \\ Golan Research Institute, University of Haifa, Katzrin, Israel
}

Received: December 18, 2013 Accepted: January 10, 2014 Published: February 11, 2014

doi:10.5296/jsss.v1i2.5099 URL: http://dx.doi.org/10.5296/jsss.v1i2.5099

\begin{abstract}
Corporal punishment is the physical punitive measures of parents against children with devastating consequences when bordering on child abuse. This has even led to legislation against corporal punishment while controversy and criticism divides researchers and practitioners as to the prohibition against moderate and functional corporal punishment which may act as an effective method of education. Limited research exists on corporal punishment and its effect on the emotional aspects of children and investigation is required due its inherent and immense cultural importance. We studied the relationship between corporal punishment in the context of parenting style and anxieties in pre-adolescent children from northern Israel (age $=11.5 \pm 0.56 \mathrm{yrs}, \mathrm{n}=101)$. A positive association between general level of parental punishment and elevated anxieties was elucidated, mainly for the children of authoritarian parents. In addition, within this group children who experienced high levels of corporal punishment were more anxious. In contrast, this was not observed in children of authoritative parents. Results reported here indicate the apparent moderating role parenting style has on corporal punishment in the context of anxieties in children and conclude that while high level of corporal punishment is harmful, moderate corporal punishment may be harmless to children in specific parenting contexts.
\end{abstract}

Keywords: Corporal Punishment, Parenting Style, Pre-adolescents, Anxiety 


\section{Introduction}

Corporal punishment by definition includes any kind of physical punitive measures (Gershoff, 2002; Xing \& Wang, 2013; Ma, Hanb, Grogan-Kaylorb, Delvab, \& Castillo, 2012; Aucoin, Paul \& Bodin, 2006) in response to a child's inappropriate behavior and may take the form of beatings, such as a spanking the buttocks, slapping, pinching, hair pulling, ear twisting and, in extreme cases, beating with a belt or a stick (Zolotor \& Puzia, 2010). Corporal punishment has been linked with poor psychological development of children and adolescents (Straus \& Paschall, 2009). This has led to corporal punishment being banned by law in 24 countries, mostly European, a number of South and Central American countries and throughout the Middle East (Zolotor \& Puzia, 2010). Even so, controversy as to the effectiveness, admissibility and legitimacy of corporal punishment divides researchers and practitioners.

Indeed, some experts contend that current legislation against corporal punishment is an intrusion into family practices, limiting the ability of parents to properly educate their children (Zolotor \& Puzia, 2010). Moreover, in recent years criticism has developed in the scientific community regarding the prohibition against corporal punishment, suggesting a systematic bias of the understanding and interpretation of empirical evidence (Baumrind, 1996; Barumrind, Larzelere, \& Cown, 2002; Larzelere \& Baumrind, 2010). The methodological criticism focuses on two main points. First, causal evidence linking corporal punishment and undesirable outcomes in children is inadequate. Second, there is a lack of consistent operational distinction between levels and forms of corporal punishment with respect to its negative effects on children's adjustment. As a result, the adverse effects of parental spanking and abusive behavior are confounded.

There is agreement among professionals of the devastating consequences of violent parental behavior bordering on child abuse. However, many professionals, along with laymen, still believe that the use of moderate and functional corporal punishment is an effective, and sometimes even necessary, method of discipline (Oas, 2010; Aucoin et al., 2006). Indeed, many countries refrain from imposing explicit legislative prohibitions on corporal punishment of children (Zolotor \& Puzia, 2010) and many parents continue to use this method for educating their children (Larzelere, Kuhn, \& Johnson, 2004; Straus \& Stewart, 1999). The literature consistently confirms that the use of corporal punishment is an effective mean of achieving compliance in children and reducing unwanted and anti-social behavior (Gershoff, 2002; Larzelere \& Kuhn, 2005). This is particularly valid under situations of coping with difficult children (Baumrind et al., 2002).

It therefore seems clear that this controversial issue requires careful investigation due to the immense educational and cultural importance it carries. Scientific inquiry regarding the effectiveness of corporal punishment as an educational tool necessitates expanding and refining the scope of research on several specific aspects. The literature discussing the aspects and potential consequences of corporal punishment on children's adjustment reveals that most studies have focused on externalized variables, such as aggressive behavior, delinquency and anti-social tendencies. The possible effects of this educational method for children's emotional functioning and development of internalized disorders have yet to be fully 
elucidated (Xing \& Wang, 2012).

There has been limited research on corporal punishment and its relationship to the specific emotional aspects of anxiety in children. For example, Rodriguez (2003) examined the relationship between parental attitudes toward severe punishment, a tendency toward abuse and symptoms of emotional distress in children. The findings show that children of parents who presented a strong tendency to use aggressive forms of education and corporal punishment reported significantly higher anxiety and depression levels, compared to the control group. These results were particularly strong in relation to symptoms of anxiety. A later longitudinal study presented evidence of a causal link between corporal punishment and internalized behavior among boys and girls (Xing \& Wang, 2012). Its findings showed that among girls, mild or severe levels corporal punishment predicted increased levels of anxiety and depression. Conversely, among boys, only severe corporal punishment significantly predicted internalized disorders, such as anxiety and depression. In both cases the reverse relationship was not significant, strengthening the evidence identifying the causal factor in the relationship between these variables.

These findings intensify the relative relationship between corporal punishment and emotional developmental variables in children, suggesting that the former may also play a crucial role in emerging emotional problems, like anxiety and depression. Even so, understanding the nature of corporal punishment in respect of negative, and even pathological, feelings of anxiety requires further research, also focusing on the identification and characterization of these relationships with specific anxiety types. Accordingly, the purpose of this study is to examine the contribution of different forms of corporal punishment as they relate to the emergence of general anxiety and specific anxiety types in preadolescent children.

Another issue which is not adequately considered when assessing the link between corporal punishment and children's development is the overall parental context in which this educational practice is administered or performed. The relevant body of research shows evidence of the importance of educational-familial climate on regulating the effects of corporal punishment on children. It has been found that parental warmth reduced levels of behavioral problems among children when exposed to corporal punishment, and the level of parental warmth reduced the strength of the relationships among corporal punishment and behavioral disorders (Ma et al., 2012). Another study showed similar support for the moderating effect of parental support, especially maternal, on the relationship between corporal punishment and depression in early adolescence (Harper, Brown, Arias, \& Brody, 2006). If so, the negative impact of corporal punishment on the emotional and behavioral adjustment measured in these studies was minor, under supportive parenting styles (e.g., parental warmth).

Finally, a recent study expanded the definition of the four parenting configurations developed by Maccoby and Martin (1983) and examined the impact of moderate corporal punishment (spanking) on behavioral and emotional variables among African-American children (Simons, Simons, \& Su, 2013). According to their findings, the effects of corporal punishment depend largely on the context of parental behavior in which it is manifested and that corporal 
punishment itself does not necessarily influence children negatively, except in extreme cases. Specifically, they compared the performance levels between groups of children of parents with different parenting styles. Higher levels of social functioning were observed in children of spanking parents who were characterized by high demandingness and responsiveness (Non-Nonsense Parents) in almost all parameters tested (except for the children of authoritative parents), as compared to most of the other children in the study. Another group of children of parents, who implemented corporal punishment, characterized by high levels of demandingness and monitoring (Punitive Parents), presented higher levels of performance in behavioral measures, as compared with children whose parents had low demandingness. This was despite the fact that corporal punishment was their main educational practice. Nonetheless, these children had diminished emotional functioning (depression) compared with the rest of the sample whose parents were characterized by a high level of responsiveness, especially those whose parents did not use corporal punishment.

Taken together, these indicate that moderate use of corporal punishment is controversial and may still be unresolved, especially in relation to children's emotional variables. Even though a significant body of studies indicates the negative potential inherent in corporal punishment, it is becoming clear that its efficacy as an educational endeavor is dependent upon other intervening variables. One of the most relevant variables outlined in this context is parenting style, and it seems necessary to account for this when examining the effects of corporal punishment on children's development. Therefore, this study will examine the relationship between parental corporal punishment and specific patterns of anxiety among children of pre-adolescent age, while taking into account parenting style.

Based on the findings in the literature, it was hypothesized that corporal punishment by parents would have a significant effect on the general level of anxiety of children. The hypothesis regarding the relationship between corporal punishment and specific patterns of anxiety in children will be examined as an open question, due to the absence of sufficient relevant literature. We also hypothesized that parenting style would play a moderating role in the relationship between parental punishment, in general, and corporal punishment in particular, pertaining to general and specific anxiety in children. In this context, we expected to find differences in these relationships between children of parents from different groups of parenting styles.

\section{Method}

\subsection{Participants and Procedure}

The study sample consisted of fifth-and sixth-grade children from regular education classes, including54 girls and 40 boys, while7 children did not report their gender $(n=101)$. The mean age of the children was $11.5 \pm 0.56 \mathrm{yrs}$ (range: $10-13 \mathrm{yrs}$ ). Younger children were excluded to rule out patterns characteristic of early development anxiety and to ensure that children were able to complete the study questionnaires satisfactorily.

Several elementary schools were targeted, upon receiving necessary approval for the study questionnaires and tools from the Ministry of Education. Convenience sampling was chosen 
due to study constraints. Three schools in Northern Israel consented to be part of the study and requests for confirmation were sent to parents for the recruitment of their son/daughter. The participants completed an anonymous questionnaires, as the parents were informed and under their supervision.

Only children who expressed personal consent, and whose parents also consented, participated in this study. The participants were instructed on how to fill out the questionnaires, prior to their distribution. In addition, a brief tutorial was given explaining the general aims of the study and the interest of the researchers to learn more about the relationship between children and their parents, as well as, their feelings during the beginning of puberty. It was clarified that no obligation to take part in the study existed and that they may withdraw at any time. The participants were asked to fill out three anonymous questionnaires (see Measures below) and specific background information (age, gender, birth order). The researcher or other persons on his behalf were present during filling of the questionnaires to answer any questions that might arise. All precautions were taken to adhere to strict ethics required in studies with children.

\subsection{Measure}

\subsubsection{Parenting Styles}

Assessment of overall parental styles, based on child self-reporting, was carried out using the questionnaire of parental authority by Buri (PAQ: Buri, 1991). It contains 30 items, 10 items per parenting style, normally used for classification of parents according to the conceptualization of Baumarind:

1) authoritative (e.g., "My parents always encouraged discussions every time I felt that the rules and restrictions in the family are not fair."),

2) authoritarian (e.g., "Even if the kids did not agree with them, my parents felt it was in our favor if they were made us do as they think fit.") and

3) permissive (e.g., "When I grew up my parents felt that the house is properly managed, children should get what they want in the family as much as the parents.").

Responses scaled from 1 ("strongly disagree") to 5 ("fully agree") and total parental score varied from 10-50, for every scale. Classification by parental style was determined by the highest score for each subject. This tool is valid with relatively high internal reliability and test-retest reliability (Buri, 1991; Smetana, 1995) and widely accepted, used in Israel and around the world, to measure the three parenting styles. The translated version has been previously shown to have good internal reliability and evidence indicates its validity (Mayselles, Scharf, \& Sholt, 2003). Internal reliability values ranging between 0.72-0.78 were obtained, for the three parenting style scales. In addition, this study found significant values of discriminant validity and criterion validity, similar to the findings of the validation used when developing the original questionnaire. For example, the correlation between the authoritarian and authoritative scales in the questionnaire was significantly negative $(r=-0.21$, $\mathrm{p}<0.05)$. The various data are shown in Table 1 . 
Table 1. Descriptive Statistics (mean, SD, $\alpha$ ) for parenting and anxiety variables

\begin{tabular}{|c|c|c|c|c|}
\hline Questionnaire & Variable & Mean & SD & $\alpha$ \\
\hline IPPS & $\begin{array}{l}\text { Punishment } \\
\text { (external response) }\end{array}$ & 2.54 & 0.49 & 0.94 \\
\hline \multirow[t]{3}{*}{ PAQ } & Permissive & 27.55 & 6.46 & 0.72 \\
\hline & Authoritarian & 29.81 & 6.83 & 0.78 \\
\hline & Authoritative & 35.30 & 6.86 & 0.73 \\
\hline \multirow[t]{6}{*}{ SCARED } & Separation anxiety & 6.87 & 3.47 & 0.70 \\
\hline & Social anxiety & 6.29 & 3.41 & 0.81 \\
\hline & School Phobia & 1.91 & 1.68 & 0.69 \\
\hline & Generalized anxiety di & 7.19 & 3.49 & 0.70 \\
\hline & Panic/Somatic & 5.55 & 4.34 & 0.82 \\
\hline & General anxiety level & 27.81 & 12.26 & 0.90 \\
\hline
\end{tabular}

Note: $100 \leq \mathrm{n} \leq 101$.

\subsubsection{Patterns of Anxiety}

For initial identification of anxiety disorders, and in order to assess the level of general anxiety and specific anxiety patterns among children in the study, the subjects completed the SCARED questionnaire (SCARED: Birmaher et al., 1997); containing 41 items divided into five variables corresponding to the classification of anxiety disorders in children according to the DSM-IV:

Panic/Somatic (e.g., "When I am afraid I feel that I'm about to pass out"),

Generalized Anxiety Disorder (e.g., "I worry that things do not work out like I want"),

Separation Anxiety (e.g., "I have bad dreams that something bad is happening to my parents"),

Social Anxiety (e.g., "I feel tense when I'm with people I do not know well"),

School Phobia (e.g., "I am worried or afraid when I need to go to school"). 
Response scales comprised of three options: 0 -'not true', 1-'sometimes true' and 2 -'often true'. A series of studies emphasize the validity of this tool for measuring anxiety in children and its scales have high reliability and validity (Birmaher et al., 1997; Birmaher et al., 1999; Muris, Merckelbach, Barkel, \& Mayer, 1999; Isolan, Salum, Osowski, Amaro, \& Manfro, 2011). The Hebrew translation of this questionnaire is also used in various studies in Israel for screening children with anxiety, including identification of patterns of specific anxiety disorders (Bar-Haim, Dan, Eshel, \& Sagi-Schwartz, 2006). Internal reliability data obtained in the study for all scales of anxiety in the questionnaire ranged from 0.69-0.90 (Table 1).

\subsubsection{Parental Punishment}

The level of punishment children are exposed to by their parents, including corporal punishment, was assessed using the method developed by Gordon et al. (IPPS: Gordon, Jines \& Norwickl, 1979). This questionnaire contains 33 items that describe situations, as similar as possible to common interactions between children and parents. Each response was given on the 5-point Likert scale of external parental punitive behavior, such as corporal punishment, raising his voice and/or denial of rights to coerce parental will. Test-retest reliability of $r=0.85$ for the scale of external punishment response was obtained for the original tool. Data for the scale for this variable obtained here has high internal reliability ranging from 0.94-0.96 (Table 1).

\section{Results}

Descriptive statistics for the different scales used to measure the variables in this study are presented and the general trends among the different scales in this study will be shown. The hypotheses were tested by correlations between parental punishment scale (IPPS), various anxiety variables (SCARED) and parenting style cross-sections. The specific effect of corporal punishment on anxiety levels was also investigated. In the absence of significant effects of demographic background variables (gender and birth order) on the level of anxiety among the study participants, the following analyses were conducted for the entire sample, regardless of its constituent groups.

In order to examine trends of the general relations among the scales of parenting (punishment and styles) and various anxiety variables, zero-order correlations were calculated. A number of major correlational trends are shown (Table 2). Significant positive correlations between the level of punishment for most of the specific anxiety patterns and general anxiety patterns were observed. The only exception was for generalized anxiety disorder and social anxiety, that were omitted from later analysis. These trends tentatively support the hypothesis of a link between corporal punishment and anxiety, showing that more severe parental discipline, though not necessarily corporal in nature, may be associated with heightened levels of anxiety in children.

Another positive correlation was observed between parents' punishment scale and the scale of authoritarian parenting style $(\mathrm{r}=0.31, \mathrm{p}<0.001)$. As expected, the correlation between the punishment scale and authoritative or permissive parenting was negative and insignificant. Accordingly, a system of negative correlations was observed among various anxiety variables 


\section{Macrothink

and the permissive and authoritative parenting styles. This contrasts with the positive correlation found between these anxiety variables and the authoritarian parenting style (Table 2).

Table 2. Pearson correlation between parental styles and punishment and anxiety variables

\begin{tabular}{|c|c|c|c|c|c|c|c|}
\hline Questionnaire & Scale & $\begin{array}{l}\text { School } \\
\text { Phobia }\end{array}$ & $\begin{array}{l}\text { Panic/ } \\
\text { Somatic }\end{array}$ & $\begin{array}{l}\text { Separation } \\
\text { Anxiety }\end{array}$ & $\begin{array}{l}\text { Generalized } \\
\text { Anxiety }\end{array}$ & $\begin{array}{l}\text { Social } \\
\text { Anxiety }\end{array}$ & $\begin{array}{l}\text { General } \\
\text { Anxiety } \\
\text { Level }\end{array}$ \\
\hline \multirow[t]{2}{*}{ IPPS } & Punishment & $0.36^{* * *}$ & $0.32^{* *}$ & $0.34^{* * *}$ & 0.13 & 0.09 & $0.31^{* *}$ \\
\hline & Authoritative & $-0.30^{* *}$ & -0.15 & -0.12 & $-0.26^{* *}$ & $-0.30^{* *}$ & $-0.29^{* *}$ \\
\hline \multirow[t]{2}{*}{ PAQ } & Authoritarian & $0.28^{* *}$ & $0.31^{* *}$ & $0.22^{*}$ & $0.42^{* * *}$ & 0.19 & $0.39^{* * *}$ \\
\hline & Permissive & $-0.28^{* *}$ & $-0.31^{* *}$ & $-0.20^{*}$ & -0.11 & $-0.34^{* * *}$ & $-0.28^{* *}$ \\
\hline
\end{tabular}

${ }^{*} p<0.05,{ }^{* *} p<0.005,{ }^{* * *} p<0.001$.

Note: $100 \leq \mathrm{N} \leq 101$.

\subsection{Moderating Role of Parenting Style}

From these trends, and relying on our working hypothesis, it is necessary to define the role parenting style has on moderating and regulating the positive relationship between punitive parenting and anxieties in children. For this purpose, the subjects were divided into three groups of parenting styles (as directed by the survey, Buri (1991)). Correlations were computed between punishment scale and children's anxiety variables for each group separately. The Pearson correlations among these parenting style cross-sections are given in Table 3. Note, the group of children with permissive parents was $5 \%$ and was dropped from the analysis due to its small size. To highlight differential trends between groups, despite the relatively small sample size of the authoritarian group, we adopted one-tailed tests of significance. 
Table 3. Pearson correlations between punishment level and anxiety categorized by parenting style

\begin{tabular}{llllllll}
$\begin{array}{l}\text { Group } \\
\text { (Punishment) }\end{array}$ & $\mathrm{n}$ & $\begin{array}{l}\text { School } \\
\text { Phobia }\end{array}$ & $\begin{array}{l}\text { Panic/ } \\
\text { Somatic }\end{array}$ & $\begin{array}{l}\text { Separation } \\
\text { Anxiety }\end{array}$ & $\begin{array}{l}\text { Generalized } \\
\text { Anxiety }\end{array}$ & $\begin{array}{l}\text { Social } \\
\text { Anxiety }\end{array}$ & $\begin{array}{l}\text { General } \\
\text { Anxiety } \\
\text { Level }\end{array}$ \\
\hline Authoritarian & 23 & $0.58^{* *}$ & $0.44^{*}$ & $0.36^{*}$ & -0.07 & 0.10 & $0.38^{*}$ \\
Authoritative & 72 & 0.21 & 0.19 & $0.26^{*}$ & 0.13 & 0.12 & 0.21 \\
\hline
\end{tabular}

${ }^{*} p<0.05,{ }^{* *} p<0.005$ (right-tail test).

Note: Permissive group was dropped due to small size.

The results show significant differences between the groups in terms of the relationship among anxiety variables and punishment level, which are indicative of the moderating role played by parenting style. Among the children of authoritarian parents, significant correlations were observed between the level of parental punishment and several specific patterns of anxiety (school phobia, panic/somatic, separation anxiety) and general anxiety level.

However, no significant correlation was observed between the variables, except separation anxiety pattern in the authoritative group, even though this group is based on a sample of more meaningful size. This confirms, in part, our expectation that parenting style may regulate or moderate the negative effects of severe parental punishment may have on anxiety in children.

\subsection{Effect of Corporal Punishment on Anxiety Levels Among Children}

To specifically examine the effects of corporal punishment on anxiety levels among children, we divided the sample into three groups ranked according to the level of corporal punishment. The classification into one of three levels of corporal punishment is based on the method of maximum response to an item. Since we are interested in corporal punishment, we collated low general punishment (scores of 1-3) as "No Corporal punishment", while categories of spanking/slapping (score $=4$ ) and hitting ( Punishment" and "High Corporal Punishment", respectively. A 3 x 2 multivariate analysis of variances (MANOVA) was used to analyze the effect of corporal punishment groups and parenting styles have on general anxiety and on the three anxiety patterns that were previously shown to be correlated with the scale of general punishment (see above).Averages and standard deviations are presented in Table 4.

The variance analyses resulted in general significant effects with respect to the punishment group $(\mathrm{F}(8,172)=4.26, \mathrm{p}<0.001)$ and parenting style $(\mathrm{F}(4,86)=5.86, \mathrm{p}<0.001)$ indicating that differences in anxiety levels are a result of corporal punishment and parental styles. Also 


\section{Macrothink Institute ${ }^{\mathrm{TM}}$}

observed was a general significant effect among anxiety variables of the interaction between corporal punishment group and parenting style $(\mathrm{F}(8,172)=3.48, \mathrm{p}<0.001)$. Detailed investigation of these main effects confirms the hypothesis relating to the specific anxiety variables tested and shows the effect of corporal punishment on general anxiety level $(F(2,89)$ $=9.77, \mathrm{p}<0.001)$, as well as, on panic/somatic anxiety $(\mathrm{F}(2,89)=7.29, \mathrm{p}=0.001)$, separation anxiety $(\mathrm{F}(2,89)=4.60, \mathrm{p}<0.05)$ and school phobia $(\mathrm{F}(2,89)=10.28, \mathrm{p}<0.001)$. Post-hoc tests (Tukey) assessing the source of differences between groups show that the level of anxiety of all tested variables is significantly higher in the 'high punishment' group in comparison with the other two corporal punishment groups. However, comparisons of the different anxiety levels between other groups of corporal punishment (i.e., no punishment and moderate corporal punishment) were not significant.

Table 4. Means and Standard Deviations General level of anxiety and specific anxiety patterns according to the level of punishment and parental style

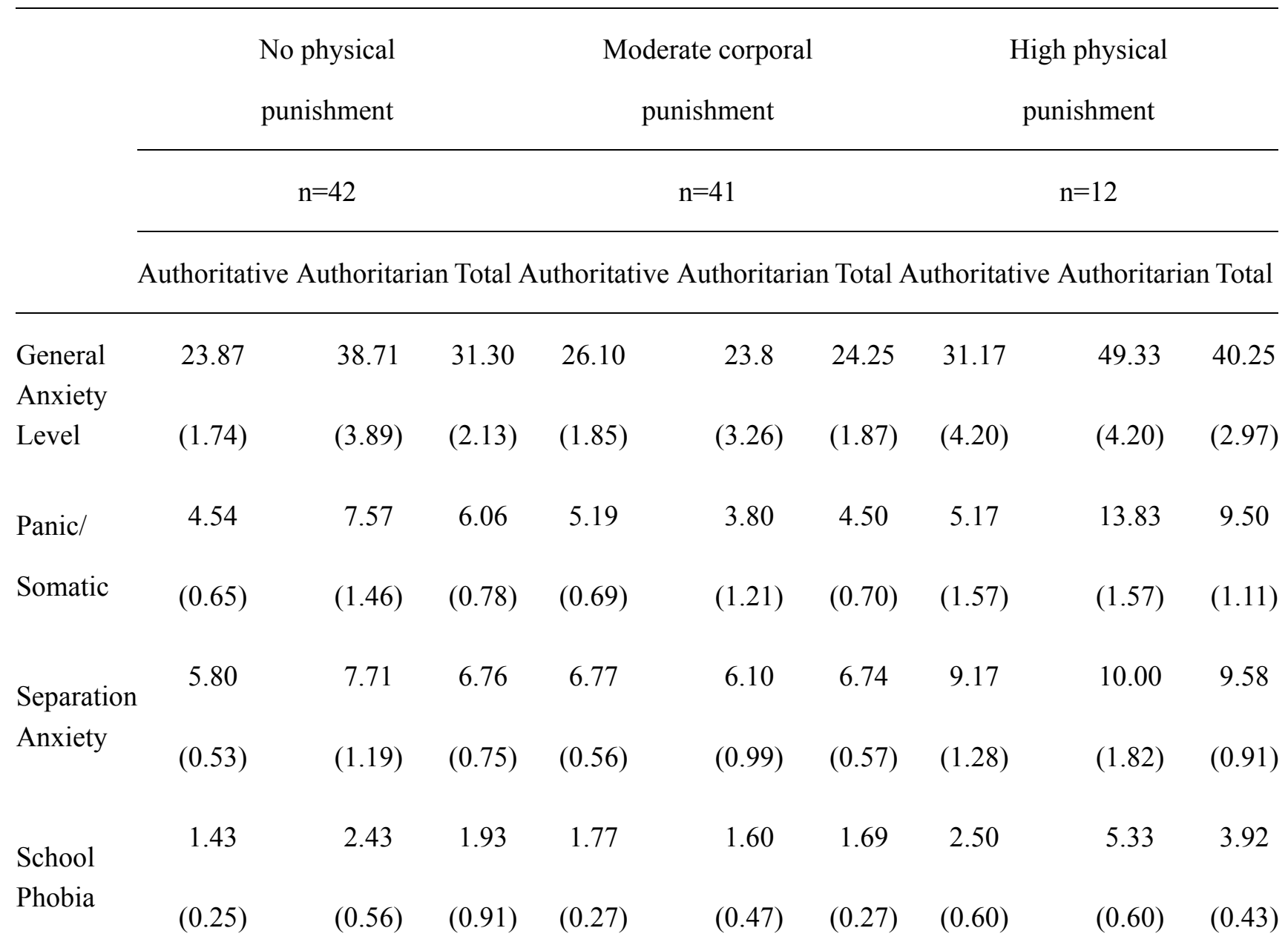

Note: Standard deviations appear in parentheses.

Examining the individual effect of parental style on anxiety variables shows, as expected, that 


\section{Macrothink}

the general anxiety level was significantly higher in children of authoritarian parents $(\mathrm{F}(1,89)$ $=13.96, \mathrm{p}<0.001)$ compared to the authoritative group. Similar effects, though less significant, were found for the specific anxiety variables of somatization/panic $(F(1,89)=$ $11.23, \mathrm{p}<0.001)$ and school phobia $(\mathrm{F}(1,89)=9.60, \mathrm{p}<0.005)$ but not for separation anxiety. The detailed interaction effect, obtained in parallel, on general anxiety level $(\mathrm{F}(1,89)=13.96$, $\mathrm{p}<0.001)$ indicates that differences in general anxiety level between parenting styles occur in the context of high corporal punishment or no corporal punishment. Intriguingly, this is not observed for moderate corporal punishment. This interaction effect also indicates that differences between punishment groups in general anxiety level occur only in children of authoritarian parents but not of authoritative parents (Figure 1). Particularly, high corporal punishment may have negative effects on the general anxiety level of children, depending upon the authoritarian style of their parents.

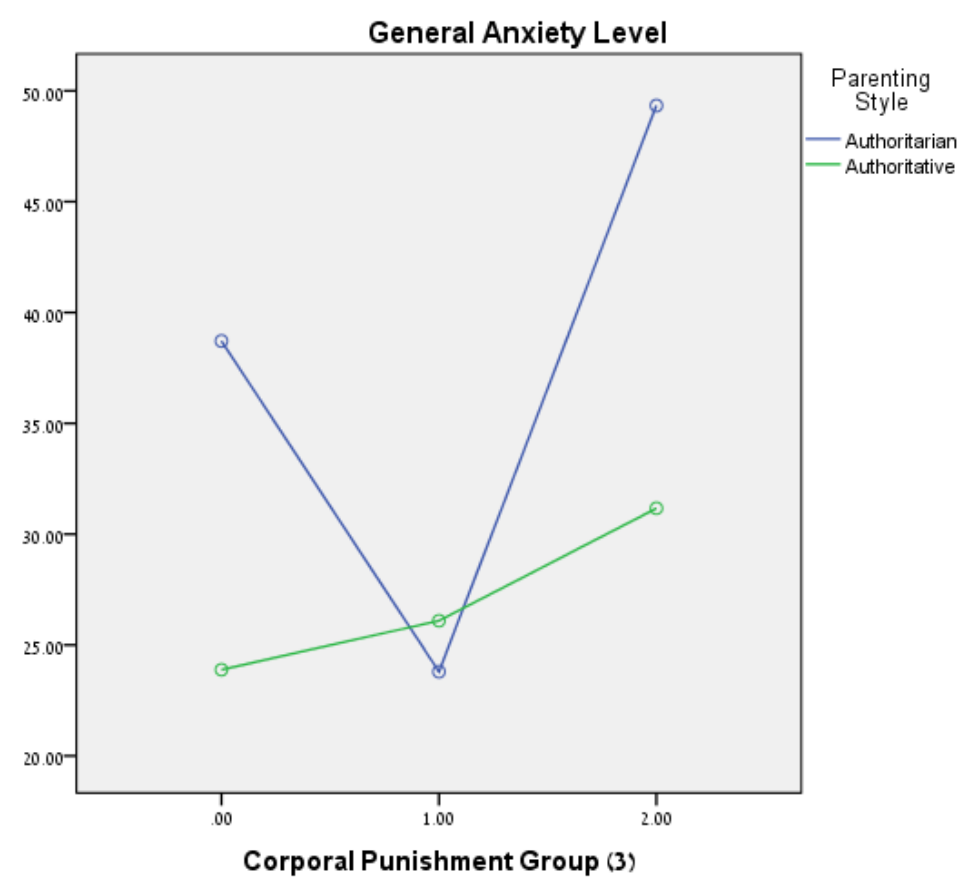

Figure 1. The interaction between corporal punishment group with parenting style predicting general anxiety level

Essentially identical statistical trends, and their significance, were also obtained for specific anxiety scales: panic/somatic (Figure 2) and school phobia (Figure 3). This, therefore, strengthens the idea of the moderating role parenting style fulfills in relation to corporal punishment and anxiety in children. 


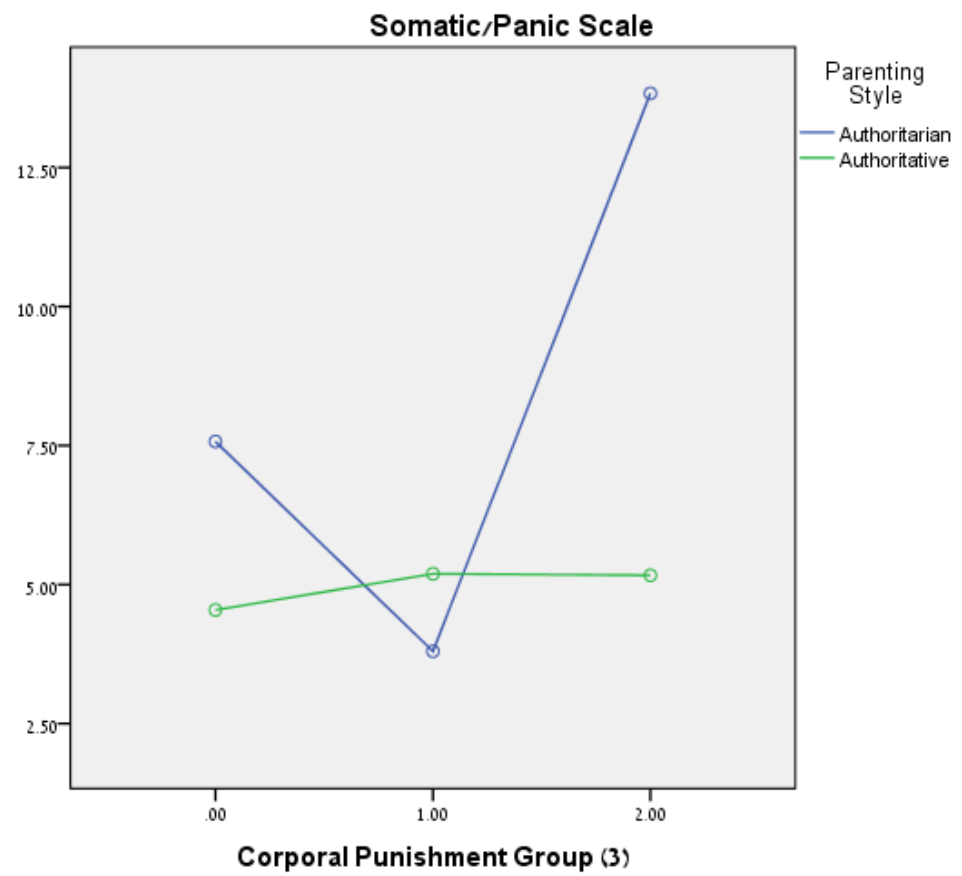

Figure 2. The interaction between corporal punishment group with parenting style predicting somatic/panic scores

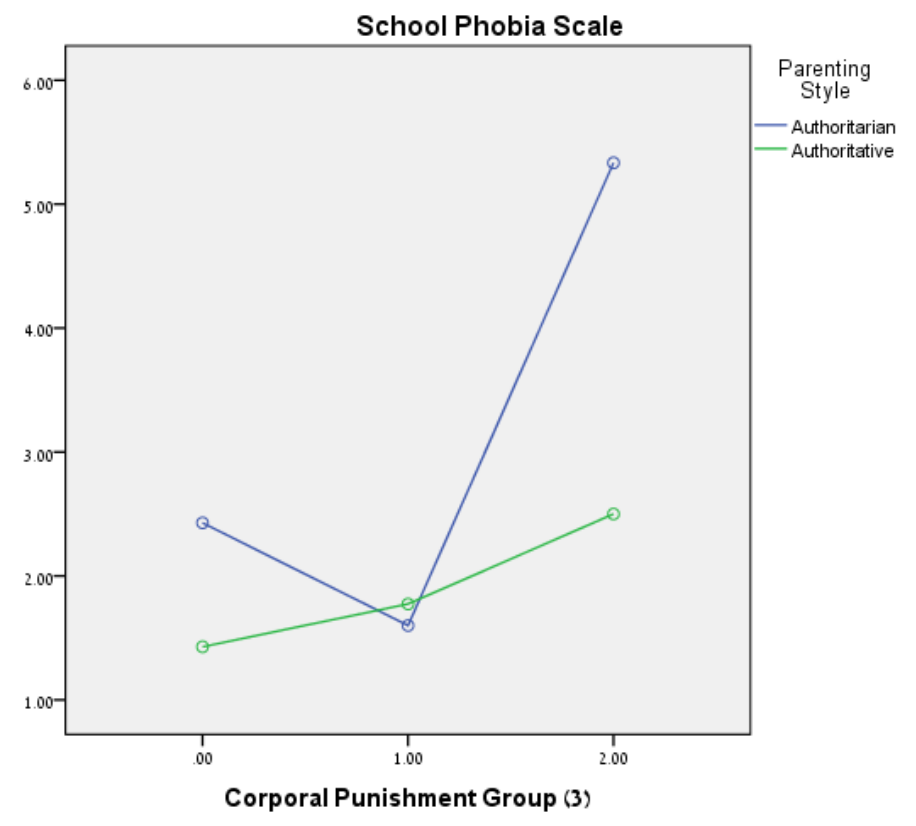

Figure 3. The interaction between corporal punishment group with parenting style predicting school phobia scores 
Noteworthy, is the similarity of the trend of the general sample (although not statistically significant in all cases) and that of children of authoritarian parents, where the level of anxiety was lowest for the moderate corporal punishment group. This contrasts results for the group without corporal punishment where anxiety was higher. More importantly, for all possible combinations examined, only high corporal punishment was found to be significantly related with increased levels of anxiety in children. Subject to the overall quality of parenting style, it may point to the importance of the intensity of corporal punishment in relation to children's anxieties, rather than on corporal punishment perse.

\section{Discussion}

The subject of this research focused on the central question of the relationship between the educational practicing of parental corporal punishment within the family and various anxieties in pre-adolescent children. Discourse concerning corporal punishment of children continues to exist, as countries around the world solidify their reservations surrounding corporal punishment of children through legislation. Still, most Western countries have yet to institute sweeping legislative prohibitions on the use of corporal punishment. Recently, researchers and professionals have challenged the fundamental axiomatic ban on educationally-driven corporal punishment. The argument being that establishment of social policy and legislation on this issue must be scientifically-based on the relevant evidence. At present, the evidence is complex, incomplete and does not clearly indicate their ineffectiveness or harmful effects these forms of education cause children (Larzelere \& Baumrind, 2010).

In context of this argument, the present study sought to determine the possible consequences of corporal punishment in the emotional context of pathological anxiety in children, which have yet to be sufficiently researched. The main research question was divided into 3 hierarchical layers tested here. First, general relationships between the level of parental punishment and overall parenting style variables to anxiety variables in children were examined. The scale of punishment used in this study measured five degrees of externalized parental punishment responses, including two forms of punishment with physical characteristics. Findings revealed a consistent positive relationship between authoritarian parenting and punitive parental style relating to most variables of anxiety measured and which may integrate with previous research linking cold, rigid and over-controlling parenting styles with anxieties in children (Mattanah, 2001; Hudson \& Rapee , 2001; Wolfradt, Hempel, \& Miles, 2003; Ginsburdg, Hopkins, Siqueland, Masia-Waener, \& Hedtke, 2004; Ginsburdg, Hopkins, Siqueland, Masia-Waener, \& Hedtke, 2004; Gershoff et al., 2010).

Furthermore, a positive relationship was identified between punishment level and authoritarian parenting and anxiety, along with negative correlations observed between most of the anxiety variables and permissive or authoritative parenting. Based on these findings and the relevant literature, we tested the hypothesis regarding the moderating role of parenting style by examining the relationship between general punishment level and anxiety variables in two groups with differing parenting styles. Correlations between high parental punishment and three different anxiety variables (somatization/panic, school phobia and 
general anxiety level) were observed in children of authoritarian parents, but not in children of authoritative parents. These may suggest that elevated parental punishment practices may not negatively affect children's anxiety, in the context of an authoritative educational climate (i.e., constant parental demandingness while providing warmth and support). This conclusion is generally consistent with a number of recent studies which found variations of the moderating, or protective, effect of parental quality in relation to adverse effects of severe parental punishment on children's emotional development (Taillieu \& Brownridge, 2013; Ma et al., 2012; Simons et al., 2013; Harper et al., 2006; Fletcher, Walls, Cook, Madison, \& Bridges, 2008). Accounting for broader educational contexts may affect the professional and empirical discourse regarding the efficacy of the use of punishment in children's education and also on the need to integrate it in educational intervention programs for children with special educational needs.

The main section of this study concentrated on examining the specific effect of corporal punishment on the general anxiety level and three specific anxiety patterns found correlated with the general punishment scale in early tests. Multivariate analysis of variance revealed significant effects for the level of corporal punishment on all anxiety variables examined (see Table 4), most of which interact with the parental style (except for the effect on separation anxiety). Effects obtained on the general anxiety level and specific patterns tested were essentially similar, and therefore will be discussed below together.

Expected differences of anxiety levels between the groups of corporal punishment were observed only in comparison to the high corporal punishment group but not compared to the moderate punishment group. In other words, the negative effect of parental corporal punishment on anxiety levels in the sample was only observed among children exposed to a high degree of corporal punishment. However, anxiety levels in the moderate corporal punishment group were not higher than anxiety levels in the group that did not experience corporal punishment. This finding is consistent with previous research showing differential effects of various forms of corporal punishment with respect to adjustment variables in children (Aucoin et al., 2006; Larzelere \& Kuhn, 2005). It may be concluded that severe corporal punishment, but not necessarily corporal punishment, per se, may be harmful with regard to anxieties of children. This is consistent with the position of Larzelere and Baumarind (2010) regarding the need to distinguish between different forms of corporal punishment in determining a framework of considerations about its negative and positive consequences on children.

The resulting interaction effect between corporal punishment and parental style on children's anxieties in the sample emphasizes the role of parenting style, in this context. It shows that the main effect of high corporal punishment is observed in children of authoritarian parents, while no differences were found in anxiety levels between corporal punishment groups among of children of authoritative parents. This affirms that the exacerbating effect of corporal punishment (even in its most severe from) on the anxieties of children takes place in the context of authoritarianism parenting, while characteristics of authoritative parenting style seems to mitigate the negative consequences assumed to occur as a result of corporal punishment. 
The differential effect of corporal punishment in the groups of parenting can be understood in the domain of three of the four principles advocated by Larzelere defining effective corporal punishment in children (Larzelere, 1993). First, effective corporal punishment should be limited to early childhood age and not to exceed adolescence in any case. Gunnoe (2013) showed that authoritative parents made little use of corporal punishment for educational purposes towered and during adolescence, in comparison with authoritarian parents. This can explain the differential effect of corporal punishment among the parenting style groups in the current study, while considering the current punishment scale limitation of reflecting the low frequency of corporal punishment usage among the group of authoritative parents.

According to Larzelere's second principle, punishment needs to serveas a backup or in combination with less aversive educational and disciplinary methods to support their effectiveness. Accordingly, effective corporal punishment cannot be used as the primary disciplining method. The term 'conditional punishment' is used to describe this form of discipline (Larzelere \& Kuhn, 2005), more likely to be seen in authoritative parents and which its impact on child development seems innocuous (Larzelere \& Baumrind, 2010). The authoritarian parent is attributed with a more consistent style of corporal punishment, in terms of frequency and extent of use. The interaction effect found here is consistent with this theoretical rationale regarding the quantitative differences in corporal punishment practiced by the two parents' styles, whose effects on the child are differentiable.

The third principle states, that effective corporal punishment may exist in the context of positive parenting in the sense of nurturing, giving praise, physical contact while minimalizing arbitrary commands and criticisms (Larzelere, 1993). This study finds support for this assumption about the importance of the overall parenting context in relation to the effects of corporal punishment (Harper, Brown, Arias, \& Brody, 2006; Ma et al., 2012; Simons et al., 2013). It is not surprising, therefore, that among the group of children to authoritative parents, characterized by a high degree of support and emotional closeness, no higher anxieties was measured as a function of the level of punishment.

The current study found no differences between the high corporal punishment group and the other two groups in anxiety levels among children of authoritative parents. This is inconsistent with the fourth principle proposed by Larzelere for effective corporal punishment (Larzelere, 1993, p. 144), stating that effective corporal punishment is defined as moderate in its power, not exceeding two open-handed beatings. The assumption accepted by most researchers and professionals, that all severe corporal punishment is offensive and harmful to the child, regardless of the circumstances (Larzelere \& Baumrind, 2010), is inconsistent with this finding. Implicitly, there are certain conditions, under definite circumstances, in which severe corporal punishment may not be harmful for children seems less reasonable and must be restricted. Instead, this result must be attributed to the methodological limitations arising from the tool to measure punishment in the current study, which was adapted to distinguish between levels of corporal punishment. As mentioned, it is possible that the screening method used to classify groups of corporal punishment is not sensitive to aspects of the frequency and timing of corporal punishment, which are directly relevant to parenting style. Therefore, supposing high-level of corporal punishment is essentially different between the two 
parenting styles would explain why no effect was observed in authoritative group, similar to that obtained for the authoritarian group.

Apart from the small sample size, the results presented here are limited in several respects. First, all measures of parenting and punishment styles rely on self-reported subjective perception of the child. This perceived parenting style by the child may not match exactly the actual style of the parent. Under this constraint, understandably, the conclusions linking punitive parenting style and various anxieties in children must be restricted. However, many researchers tend to attribute a great deal of importance to the child's perception of the parent's characteristics (Steinberg, 2001; Barber, 1996), emphasizing its importance in relation to developmental and adaptive variables. Furthermore, Campbell and Fiske (1959) reported the methodological significance relating to the validity of findings stems from a single source and warned of the potential inflation of correlation biases this may cause. Moreover, the various anxiety patterns were measured using a single measurement tool, which was also the source of the total anxiety score. However, for a more advanced etiological examination of the various patterns of anxiety in the context of punitive parenting styles, it is essential to make use of more stringent diagnostic methods designed to identify actual anxiety disorders. Finally, the present study, as well as in most studies, based correlative findings which do not give meaningful information on the direction of the parent-child effect. Although interpretation of these results regarding the relationship between corporal punishment and anxieties implies parental influence, the possibility that the dominant effect is actually reversed, remains open.

\section{References}

Aucoin, K. J., Paul, P. J., \& Bodin, D. B. (2006). Corporal punishment and child adjustment. Journal of Applied Developmental Psychology, 27, 527-541. http://dx.doi.org/10.1016/j.appdev.2006.08.001

Bar-Haim, Y., Dan, O., Eshel, Y., \& Sagi-Schwartz A. (2007). Predicting children's anxiety from early attachment relationships. Journal of Anxiety Disorders, 21, 1061-1068. http://dx.doi.org/10.1016/j.janxdis.2006.10.013

Barber, B. K. (1996). Parent psychological control: revisiting neglected construct. Child Development, 67, 3296-3319. http://dx.doi.org/10.2307/1131780

Baumrind, D. (1996). A blanket injunction against disciplinary use of spanking is not warranted by the data. Pediatrics, 98, 828-831.

Barumrind, D., Larzelere, R. E., \& Cown, P. A. (2002). Ordinary Physical Punishment: Is It Harmful? Comment on Gershoff (2002). Psychological Bulletin, 128(4), 580-589. http://psycnet.apa.org/doi/10.1037/0033-2909.128.4.580

Birmaher, B., Brent, D. A., Chiappetta, L., Bridge, J., Monga, S., \& Baugher, M. (1999). Psychometric properties of the screen emotional disorders (SCARED): A replication study. Journal of American Child and Adolescents Psychiatry, 38(10), 1230-1236. http://dx.doi.org/10.1016/j.janxdis.2009.04.003 
Buri, J. R. (1991). Parental Authority Questionnaire. Journal of Personality Assessment, 57(1), 110-119. http://dx.doi.org/10.1207/s15327752jpa5701_13

Campbell, D. T., \& Fiske, D. W. (1959). Convergent and Discriminant validation by the multitrait-multimethod matrix. Psychological Bulletin, 56, 81-105. http://dx.doi.org/10.1037/h0046016

Fletcher, A. C., Walls, J. K., Cook, E. C., Madison, K. J., \& Bridges, T. H. (2008). Parenting Style as a Moderator of Associations Between Maternal Disciplinary Strategies and Child Well-Being. Journal of Family Issues, 29(12), 1724-1744. http://dx.doi.org/10.1177/0192513X08322933

Gershoff, E. T. (2002). Parental corporal punishment and associated child Behaviors and experiences: A meta-analytic and theoretical review. Psychological Bulletin, 128, 539-579. http://dx.doi.org/10.1037//0033-2909.128.4.539

Gershoff, E. T., Gorgan-Kaylor, A., Lasford, J. E., Chang, L., Zelli, A., Deater-Deckard, K., \& Dodge, K. A. (2010). Parent Discipline Practices in an International Sample: Associations With Child Behaviors and Moderation by Perceived Normativeness. Child Development, 81(2), 487-502. http://dx.doi.org/10.1111\%2Fj.1467-8624.2009.01409.x

Ginsburdg, G. S., Hopkins, J., Siqueland, L., Masia-Waener, C., \& Hedtke, K. A. (2004). Anxiety Disorders in Children: Family Matters. Cognitive and Behavioral Practice, 11, 28-43. http://dx.doi.org/10.1016/S1077-7229(04)80005-1

Gordon. D. A., Jines. R. H., \& Norwickl. S. J. (1979). A measure of intensity of parental punishment. Journal of Personality Assessment, 43, 485-496. http://dx.doi.org/10.1207/s15327752jpa4305_9

Gunnoe, M. L. (2013). ASSOCIATIONS BETWEEN PARENTING STYLE, PHYSICAL DISCIPLINE, AND ADJUSTMENT IN ADOLESCENTS' REPORTS. Psychological Reports: Disability \& Trauma, 112(3), 933-975. http://dx.doi.org/10.2466/15.10.49.PR0.112.3.933-975

Harper, F. W. K, Brown, A. M., Arias, I., \& Brody, G. (2006). Corporal Punishment and Kids: How Do Parent Support and Gender Influence Child Adjustment? Journal of Family Violence, 21(3), 197-207. http://dx.doi.org/10.1007/s10896-006-9018-2

Hudson, J. L. \& Rapee, R. M. (2001). Parent-child interactions and anxiety disorders: An observational study. Behavior Research and Therapy, 39, 1411-1427. http://dx.doi.org/10.1016/S0005-7967(00)00107-8

Isolan, L., Salum, G. A., Osowski, A. T., Amaro, E., \& Manfro, G. G. (2011). Psychometric properties of the Screen for Child Anxiety Related Emotional Disorders (SCARED) in Brazilian children and adolescents. Journal of Anxiety Disorders, 25, 741-748. http://dx.doi.org/10.1016/j.janxdis.2011.03.015

Larzelere, R. E. (1993). Empirically Justified Uses of Spanking: Toward a Discriminating View of Corporal Punishment. Journal of Psychology and Theology, 21(2), 142-147. 
Larzelere, R. E. \& Baumrind, D. (2010). ARE SPANKING INJUNCTIONS SCIENTIFICALLY SUPPORTED? LAW AND CONTEMPORARY PROBLEMS, 73, 57-74.

Larzelere, R. E., \& Kuhn, B. (2005). Comparing child outcomes of physical punishment and alternative disciplinary tactics: A meta-analysis. Clinical Child and Family Psychology Review, 8, 1-38. http://dx.doi.org/10.1007/s10567-005-2340-z

Larzelere, R. E., Kuhn, B. R., \& Johnson, B. (2004). The intervention selection bias: An under recognized confound in intervention research. Psychological Bulletin, 130, 289-303. http://dx.doi.org/10.1037/0033-2909.130.2.289

Ma, J., Hanb, Y., Grogan-Kaylorb, A., Delvab, J., \& Castillo, M. (2012). Corporal punishment and youth externalizing behavior in Santiago, Chile. Child Abuse \& Neglect, 36, 481-490. http://dx.doi.org/10.1016/j.chiabu.2012.03.006

Maccoby, E. E., \& Martin, J. A. (1983). Socialization in the context of the family: Parent-child interaction. In P. H. Mussen (Series Ed.) \& E. M. Hetherington (Vol. Ed.), Handbook of child psychology: Vol. 4. Socialization, personality, and social development(pp. 1-101). New York: Wiley.

Mattanah, J. F. (2001). Parental psychological autonomy and children's academic competence and behavioral adjustment in late childhood: more than just limit-setting and warmth. Merrill-Palmer Quarterly, 47, 355-376. http://dx.doi.org/10.1353/mpq.2001.0017

Mayseless, O., Scharf, M., \& Sholt, M. (2003). From Authoritative Parenting Practices to an Authoritarian Context: Exploring the Person-Environment Fit. Journal of research on adolescence, 13(4), 427-456. http://dx.doi.org/10.1046/j.1532-7795.2003.01304002.x

Muris, P., Merckelbach, H., van Brakel, A., \& Mayer, B. (1999). The revised version of the Screen for Child Anxiety Related Emotional Disorders (SCARED-R): further evidence for its reliability and validity. Anxiety, Stress, and Coping, 12, 411-425. http://dx.doi.org/10.1080/10615809908249319

Oas, P. T. (2010). Current Status on Corporal Punishment With Children: What the Literature Says. The American Journal of Family Therapy, 38, 413-420. http://dx.doi.org/10.1080/01926187.2010.514214

Rodriguez, C. M. (2003). Parental Discipline and Abuse Potential Affects on Child Depression, Anxiety and Attributions. Journal of Marriage and Family, 65, 809-817. http://dx.doi.org/10.1111/j.1741-3737.2003.00809.x

Simons, L. S., Simons, R. L., \& Su, X. (2013). Consequences of Corporal Punishment Among African Americans: The Importance of Context and Outcome. Journal of Youth and Adolescence, 42, 1273-1285. http://dx.doi.org/10.1007/s10964-012-9853-9

Smetana, J. G. (1995). Parenting Styles and Conception of Parental Authority during Adolescence. Child Development, 66, 299-316. http://dx.doi.org/10.2307/1131579

Steinberg, L. (2001). We Know some things: parent-adolescent relationships in retrospect and 
prospect. Journal of research on Adolescence, 11(1), 1-19. http://dx.doi.org/10.1111/1532-7795.00001

Straus, M. A., \& Paschall, L. P. (2009). Corporal Punishment by Mothers and Development of Children's Cognitive Ability: A Longitudinal Study of Two Nationally Representative Age Cohorts. Journal of Aggression, Maltreatment \& Trauma, 18, 459-483. http://dx.doi.org/10.1080/10926770903035168

Straus, M. A., \& Stewart, J. H. (1999). Corporal punishment by American parents: National data on prevalence, chronicity, severity, and duration, in relation to child and family characteristics. Clinical Child and Family Psychology Review, 2, 55-70. http://dx.doi.org/10.1023/A:1021891529770

Taillieu, T. L., \& Brownridge, D. A. (2013). Aggressive Parental Discipline Experienced in Childhood and Internalizing Problems in Early Adulthood. Journal of Family Violence, 28, 445-458. http://dx.doi.org/10.1007/s10896-013-9513-1

Wolfradt, U., Hempel, S., \& Miles, J. N. V. (2003). Perceived parenting styles, depersonalisation, anxiety and coping behavior in adolescents. Personality and Individual Differences, 34, 521-532. http://dx.doi.org/10.1016/S0191-8869(02)00092-2

Xing, X., \& Wang, W. (2013). Sex differences in the reciprocal relationships between mild and severe corporal punishment and children's internalizing problem behavior in a Chinese sample. Journal of Applied Developmental Psychology, 34, 9-16. http://dx.doi.org/10.1016/j.appdev.2012.09.004

Zolotor, A. J., \& Puzia, M. E. (2010). Bans against Corporal Punishment: A Systematic Review of the Laws, Changes in Attitudes and Behaviours. Child Abuse Review, 19, 229-247. http://dx.doi.org/10.1002/car.1131

\section{Copyright Disclaimer}

Copyright reserved by the author(s).

This article is an open-access article distributed under the terms and conditions of the Creative Commons Attribution license (http://creativecommons.org/licenses/by/3.0/). 